\title{
Planispiral Burrows from a Recent Lacustrine Beach, Gander Lake, Newfoundland
}

\author{
ROBERT B. MACNAUGHTON
}

Geological Survey of Canada, 3303 - 33 Street NW, Calgary, Alberta T2L 2A7 Canada; e-mail: romacnau@NRCan.gc.ca

MacNaughton, Robert B. 2003. Planispiral burrows from a Recent lacustrine beach, Gander Lake Newfoundland. Canadian Field-Naturalist 117(4): 577-581.

Simple horizontal, planispiral burrows occur in Recent beach sediments on the south shore of Gander Lake, Newfoundland. The burrows apparently represent deposit feeding, possibly by an arthropod. This occurrence extends the known environmental range of such traces into lacustrine settings and illustrates that such behaviour is not exclusive to marine settings.

Key Words: ichnology, lacustrine, Recent, palaeoecology, Newfoundland.

Ichnology is the study of the physical records of behaviour, including, for example, tracks, trails, burrows, and borings (Bromley 1990). Studies are undertaken both in fossil and Recent contexts (palichnology and neoichnology, respectively). Fossilised traces are referred to as "trace fossils" or "ichnofossils" and are classified using Linnean binominal nomenclature. Although much ichnological research is focused on the fossil record, neoichnology can provide crucial data when interpreting ancient behaviours (e.g., Schäfer 1972; Chamberlain 1975; Ratcliffe and Fagerstrom 1980; Metz 1987).

With the development of ichnology as a science has come the awareness that trace fossils are strongly influenced by environmental limiting factors and that, as a result, assemblages of trace fossils are potent palaeoecological and palaeoenvironmental tools (Frey et al. 1990). However, individual ichnotaxa can occur in a broad spectrum of depositional settings. This note reports an occurrence of horizontal, planispiral burrows in Recent beach sediments on the shore of Gander Lake, Newfoundland (Figure 1). Although such traces have been reported from a number of Recent and ancient depositional settings (see below), they are still widely considered to be essentially of marine (especially deep-marine) origin and have been used as a line of evidence for marine deposition (e.g., Mason et al. 1983). This contribution describes the burrows, deduces their probable ethology, and comments on their palaeoecological significance.

\section{Physical Setting}

The burrows were observed on the surface of a beach on the south shore of Gander Lake, Newfoundland, Canada. Gander Lake is an elongate, inland body of fresh water with no marine influence. The lake is $47 \mathrm{~km}$ long with an average width of $1.9 \mathrm{~km}$ and a surface area of 11500 ha (Batterson and Vatcher 1991). The lake's surface elevation is $25 \mathrm{~m}$ above sea level and depth soundings of at least $249 \mathrm{~m}$ below sea level have been reported (Jenness 1960).
The beach on which the burrows were observed is approximately $90 \mathrm{~m}$ east of the mouth of Fifteen Mile Brook (Figure 1). At the time of study, the beach was approximately $3 \mathrm{~m}$ wide by $24 \mathrm{~m}$ long. It passed on the landward side into forest-covered glacio-fluvial sand and gravel (Figure 1), from which it was probably, in part, derived (cf., Batterson and Vatcher 1991). Small driftwood logs were scattered over the beach. The beach surface consisted of damp to wet (but not water-saturated), muddy to silty, fine- to mediumgrained sand containing local concentrations of finely comminuted organic detritus. Grain-size distribution varied over a few tens of centimetres or less, with some areas dominated by silty, fine-grained sand and others by fine- to medium-grained sand. The burrows occurred in both grain-size settings.

\section{Description of Burrows}

Four horizontal, planispiral burrows were observed (Figure 2), preserved as positive features on the beach surface. No producer was recovered. The diameter of the spirals ranged from 4 to $6 \mathrm{~cm}$ while burrow diameters ranged from 2 to $3 \mathrm{~mm}$. Relief above the beach surface was approximately $1 \mathrm{~mm}$. The burrows were irregularly annulate along their length and contained an apparently structureless fill. Two of the burrows (Figure 2A, B) displayed tight central coils that became progressively more open outward, while the other burrows (Figure 2B) remained tightly coiled. The burrows that became less tightly coiled outward (Figure $2 \mathrm{~A}, \mathrm{~B})$ also differed from the tightly coiled forms in being more regularly coiled. In both types of burrows the central termination was unclear, but was raised slightly above the rest of the burrow. There was no evidence that the sediment surface had been broken at the central termination. One each of the tightly coiled and open-coiled burrows displayed dextral coiling, while the others showed sinistral coiling. In terms of comparisons with the palichnological record, the burrows, especially the regularly coiled examples, show some morphological affinity with Spirodesmos archi- 


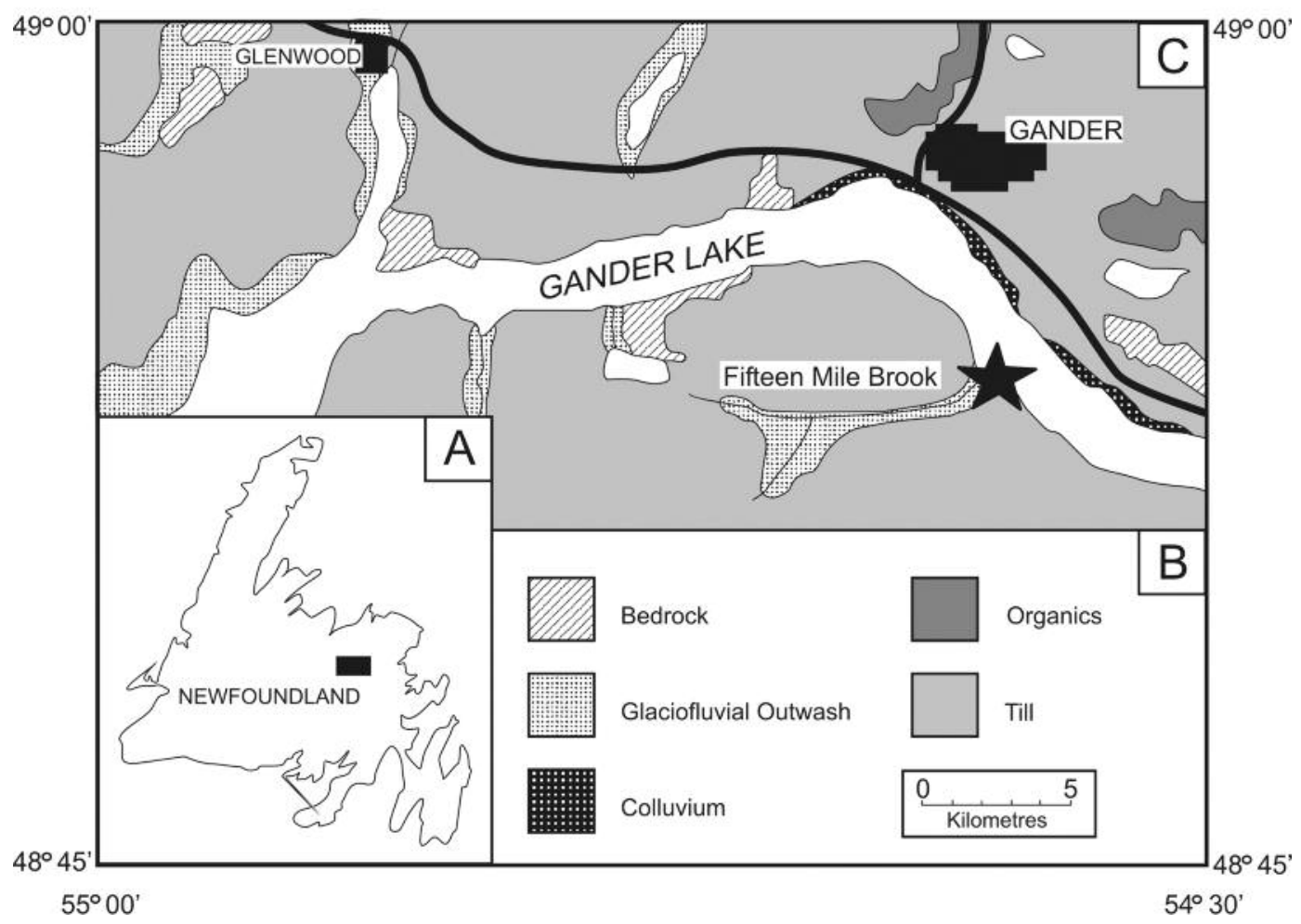

FIGURE 1: Location map. (A) Sketch map of province of Newfoundland. Black box shows location of study area. (B) Legend for main location map. (C) Map showing Quaternary geology of the study area (after Batterson and Vatcher, 1991) and the location of the burrow occurrence on the south shore of Gander Lake (star).

medeus (Huckriede 1952), although Spirodesmos does not typically have a raised central area. It should also be noted that there is some question as to whether Spirodesmos archimedeus properly belongs within Spirodesmos, the type species of which, Spirodesmos interruptus, consists of short, individual segments arranged in a planispiral form (Häntzschel 1975).

One burrow (Figure 2B) continued outward as a simple, irregularly turning, horizontal burrow. Two other specimens may have done so prior to weathering, as the outer termination of the spirals pointed toward adjacent, partially weathered, horizontal burrows.

The beach surface also displayed several other types of biogenic structures. These included simple horizontal burrows in positive relief (comparable to Planolites in the fossil record), as well as branching horizontal burrows (Figure 2B) and randomly self-crossing horizontal burrows in positive relief (comparable to Gordia or Helminthoidichnites). Less common traces included bilobate, positive-relief trails (similar to Aulichnites), poorly preserved zig-zagging traces (comparable to Plangtichnus, but see Buatois and Mángano 1993, on the status of this ichnogenus), and poorly preserved strings of pellets. Tracks of Moose (Alces alces) and various birds were also present.

\section{Interpretation of Behaviour}

Although it was not possible to recover the producer of these burrows or to observe it producing them, it is nonetheless possible to discuss the burrows' probable ethologic significance. Although planispiral burrows can reflect a number of behaviours, most can be discounted in this case. Mucous-soaked networks of tightly-coiled spiral burrows produced in intertidal flats by the paraonid polychaete, Paraonis fulgens (Röder 1971; Schäfer 1972; Risk and Tunnicliffe 1978), serve to trap migrating benthic diatoms, which are then devoured (Röder 1971). However, these networks extend up to $30 \mathrm{~cm}$ downward into the sediment and represent a behaviour adapted to a specific ecological niche found only on intertidal fine-sand or mud flats (Bromley 1990). Thus they are not likely analogues for the Gander Lake burrows. Likewise, although some deep-marine planispiral traces may have been used for cultivation of bacteria or fungi (Seilacher 

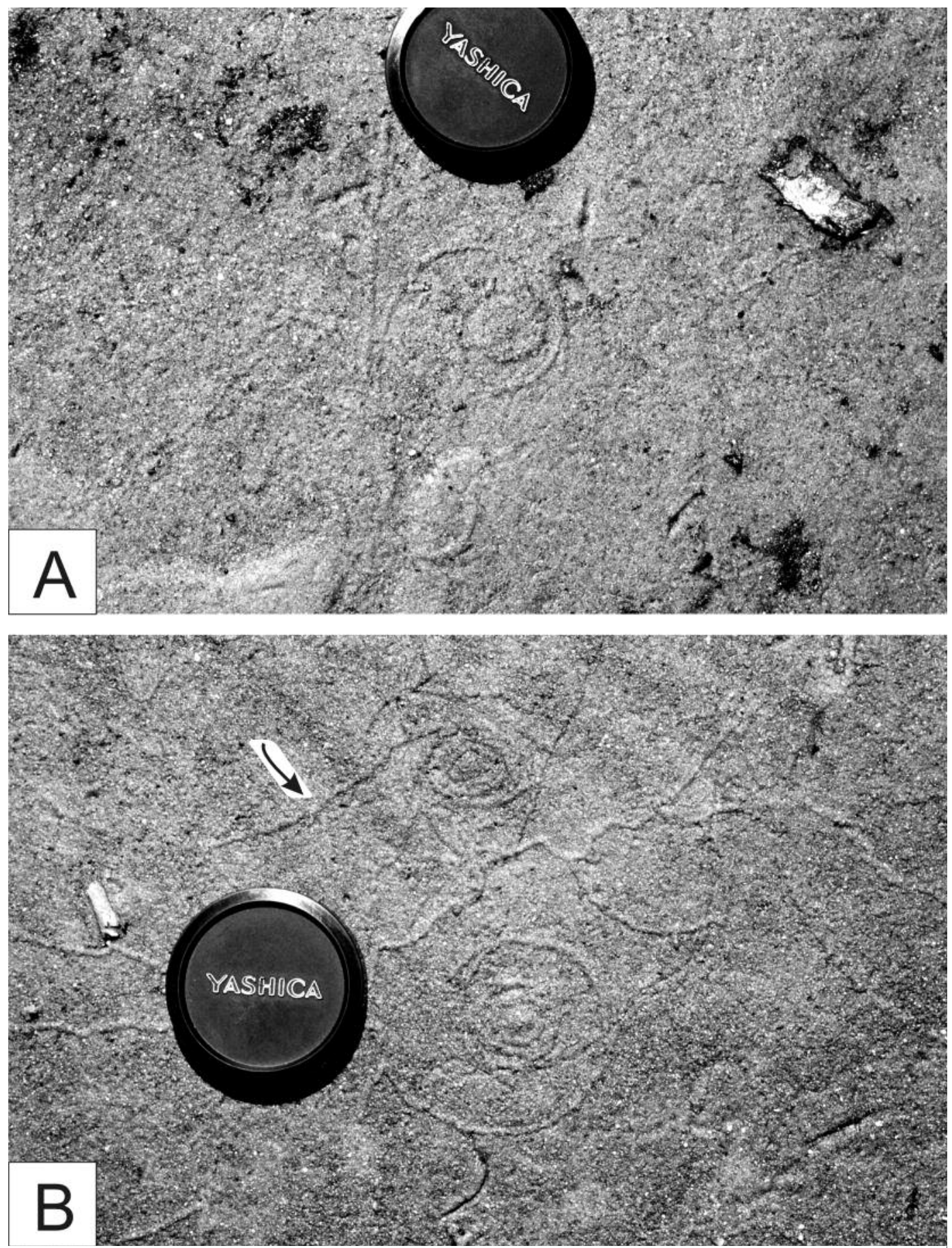

FIGURE 2: Photographs of the planispiral burrows. Lens cap is $56 \mathrm{~mm}$ in diameter. (A) Burrow with slightly raised central area and progressively more open outward coiling. Note possible continuation of burrow toward bottom of photograph. (B) Planispiral burrow near top of photograph shows tight, slightly irregular coiling and continues to left of picture as a simple, horizontal burrow (indicated by arrow). Example near bottom of photograph displays coils that become less tight outward and a raised central area. Note horizontal burrow with apparent branches extending from centre of photograph to top right. 
1977; Miller 1991), such structures were presumably open burrows while the present material is apparently backfilled.

In modern deep-marine settings, planispiral coils are commonly produced by detritus-feeding enteropneusts (acorn worms: Hemichordata) as faecal castings (Bourne and Heezen 1965; Heezen and Hollister 1971). Planispiral burrowing permits efficient mining of nutrients without reburrowing previously processed sediment (Bourne and Heezen 1965). Although the present material consists of infaunal burrows rather than faecal castings, deposit feeding would have been an effective strategy and is most probably the behaviour represented by the burrows. Previously reported shallow-marine (Ecca Group, Permian, South Africa; Mason et al. 1983) and non-marine (Mansfield Formation, Lower Pennsylvanian, Indiana; Archer and Maples 1984) planispiral trace fossils probably also represent deposit feeding.

Any comment regarding a possible producer must be speculative. However, the irregularly annulate nature of the Gander Lake burrows is similar to the appearance of feeding burrows produced by some small, non-marine arthropods, notably beetles (cf., Chamberlain 1975; Ratcliffe and Fagerstrom 1980). Metz (1987, p. 190) documented a ground beetle larva that produced a planispiral trace in an ephemeral puddle, although the trace's detailed morphology was quite different from the present examples.

\section{Palaeoecological Significance}

These burrows may help to address the origin of structures from the Upper Triassic of Pennsylvania, described by Metz (1999) as probable scratch circles produced by plants. Metz (1999) figured a set of roughly concentric, arc-shaped structures in convex relief on the bottom surface of a bed. He discussed their possible origin as feeding burrows, but rejected this interpretation based on the paucity of infaunal burrows in the rest of the succession. However, the structures described by Metz (1999) show lobate terminations and cross-sections, rather than the sharper, more angular morphology typical of other documented scratch circles (Metz 1991). They also lack the strong concentricity that typifies Recent (e.g., Brookfield 1992) and ancient (Prentice 1962; Metz 1991; Rindsberg 1994) scratch circles. The material described by Metz (1999) somewhat resembles the more irregular examples of the burrows described herein and may thus represent incompletely preserved planispiral burrows. Interestingly, like the Gander Lake material, the material described by Metz (1999) comes from a lake-margin setting, although the Triassic material apparently formed on a silty to muddy substrate rather than a sandy one.

In the stratigraphic record, planispiral traces are most commonly reported from deep-marine deposits, where they are part of an important morphologic category of trace fossils, the graphoglyptids (Miller 1991).
In rare cases, however, such traces have been reported from shallow-marine (Mason et al. 1983) and non-marine (floodplain) deposits (Archer and Maples 1984). In the Recent, planispiral traces have been reported from the deep sea (Bourne and Heezen 1965) and, in one case, from ephemeral puddles (Metz, 1987). The intertidal burrow networks of Paraonis fulgens (see above), represent a more complex and "three-dimensional" style of burrowing (Schäfer 1972; Risk and Tunnicliffe 1978) and so are not strictly comparable to the burrows described in this contribution.

To my knowledge, this is the first formal report of planispiral burrows from any lacustrine setting. It thus adds to a growing database of studies illustrating the potentially high diversity of non-marine traces, both Recent and fossil (e.g., Tevesz and McCall 1982; Metz 1987; Maples and Archer 1989; Pickerill 1992; Buatois et al. 1998). In addition, this report, along with those of Metz (1987) and Archer and Maples (1984), indicates that the presence of planispiral burrows in a stratigraphic succession cannot, in and of itself, be used as evidence for a marine or marineinfluenced depositional setting. Finally, this material re-emphasises the potentially broad environmental distributions of many common trace fossil taxa. (For additional examples, see, e.g., Fitzgerald and Barrett 1986; Pickerill 1990, 1995; Stanley and Pickerill 1993).

\section{Acknowledgments}

The burrows described in this paper were found during a study of the tectonic history of central Newfoundland, conducted by Laurel Goodwin and funded by a Natural Sciences and Engineering Research Council operating grant to Paul F. Williams (University of New Brunswick). I thank Laurel and Paul for encouraging ancillary research. J.-P. Zonneveld, R. Metz, G. C. Cadée, and two anonymous, journal-appointed reviewers are thanked for their reviews of this manuscript. B. Rutley provided sterling assistance with photographs. Geological Survey of Canada contribution 2000190.

\section{Literature Cited}

Archer, A. W., and C. G. Maples. 1984. Trace-fossil distribution across a marine-to-nonmarine gradient in the Pennsylvanian of southwestern Indiana. Journal of Paleontology 58: 448- 466.

Batterson, M. J., and S. Vatcher. 1991. Quaternary geology of the Gander (NTS 2D/15) map area. In Current Research, Newfoundland Department of Mines and Energy, Geological Survey Branch, Report 91-1, pages 1-12.

Bourne, D. W., and B. C. Heezen. 1965. A wandering enteropneust from the abyssal Pacific and the distribution of "spiral" tracks on the sea floor. Science 150: 60-63.

Brookfield, M. E. 1992. Eolian systems. Pages 143-156 in Facies Models: Response to Sea Level Change. Edited by R. G. Walker and N. P. James. Geological Association of Canada, St. John's, Newfoundland.

Buatois, L. A., and M. G. Mángano. 1993. The ichnotaxonomic status of Plangtichnus and Treptichnus. Ichnos 2: 217-224 
Buatois, L. A., M. G. Mángano, J. F. Genise, and T. N. Taylor. 1998. The ichnologic record of the continental invertebrate invasion: evolutionary trends in environmental expansion, ecospace utilization, and behavioral complexity. Palaios 13: 217-240.

Bromley, R. G. 1990. Trace Fossils: Biology and Taphonomy. Unwin Hyman, London. 280 pages.

Chamberlain, C. K. 1975. Recent lebensspuren in nonmarine aquatic environments. Pages 431-458 in The Study of Trace Fossils. Edited by R. W. Frey. Springer-Verlag, New York.

Fitzgerald, P. G., and P. J. Barrett. 1986. Skolithos in a Permian braided river deposit, southern Victoria Land, Antarctica. Palaeogeography, Palaeoclimatology, Palaeoecology 52: 237- 247.

Frey, R. W., S. G. Pemberton, and T. D. A. Saunders. 1990. Ichnofacies and bathymetry: a passive relationship. Journal of Paleontology 64: 155-158.

Hantzschel, W. 1975. Treatise on Invertebrate Paleontology, Part W. Miscellanea, Supplement 1. Trace Fossils and Problematica. Geological Society of America, Boulder. 269 pages

Heezen, B. C., and C. D. Hollister. 1971. The Face of the Deep. Oxford University Press, New York. 659 pages.

Huckriede, R. 1952. Eine spiralförmige Lebensspur aus dem Kulmkieselschiefer von Biedenkopf an der Lahn (Spirodesmos archimedeus n. sp.). Paläontologische Zeitschrift 26: 175-180.

Jenness, S. E. 1960. Late Pleistocene glaciation of eastern Newfoundland. Bulletin of the Geological Society of America 71: 161-179.

Maples, C. G., and A. W. Archer. 1989. The potential of Paleozoic non-marine trace fossils for paleoecological interpretations. Palaeogeography, Palaeoclimatology, Palaeoecology 73: 185-195.

Mason, T. R., I. G. Stanistreet, and R. Tavener-Smith. 1983. Spiral trace fossils from the Permian Ecca Group of Zululand. Lethaia 16: 241-247.

Metz, R. 1987. Insect traces from nonmarine ephemeral puddles. Boreas 16: 189-195.

Metz, R. 1991. Scratch circles from the Towaco Formation (Lower Jurassic), Riker Hill, Roseland, New Jersey. Ichnos 1: 233-235.

Metz, R. 1999. Scratch circles: a new specimen from a lake-margin deposit of the Passaic Formation (Upper Triassic), Douglassville, Pennsylvania. Northeastern Geology and Environmental Sciences 21: 179-180.

Miller, W., III. 1991. Paleoecology of graphoglyptids. Ichnos 1: $305-312$.
Pickerill, R. K. 1990. Nonmarine Paleodictyon from the Carboniferous Albert Formation of southern New Brunswick. Atlantic Geology 26: 157-163.

Pickerill, R. K. 1992. Carboniferous nonmarine invertebrate ichnocoenoses from southern New Brunswick, eastern Canada. Ichnos 2: 21-35.

Pickerill, R. K. 1995. Deep-water marine Rusophycus and Cruziana from the Ordovician Lotbinière Formation of Quebec. Atlantic Geology 31: 103-108.

Prentice, J. E. 1962. Some sedimentary structures from a Weald Clay Sandstone at Warnham Brickworks, Horsham, Sussex. Proceedings of the Geologists' Association 73: 171-185.

Ratcliffe, B. C., and J. A. Fagerstrom. 1980. Invertebrate lebensspuren of Holocene floodplains: their morphology, origin and paleoecological significance. Journal of Paleontology 54: 614-630.

Rindsberg, A. K. 1994. Ichnology of the Upper Mississippian Hartselle Sandstone of Alabama, with notes on other Carboniferous formations. Geological Survey of Alabama, Bulletin 158. 107 pages.

Risk, M. J., and V. J. Tunnicliffe. 1978. Intertidal spiral burrows: Paraonis fulgens and Spiophanes wigleyi in the Minas Basin, Bay of Fundy. Journal of Sedimentary Petrology 48: 1287-1292.

Röder, H. 1971. Gangsysteme von Paraonis fulgens Levinsen 1883 (Polychaeta) in okologischer, ethologischer und aktuopaläontologischer Sicht. Senckenbergiana Maritima 3: 3-51.

Schäfer, W. 1972. Ecology and Paleoecology of Marine Environments. University of Chicago Press, Chicago. 568 pages.

Seilacher, A. 1977. Pattern analysis of Paleodictyon and related trace fossils. Pages 289-334 in Trace Fossils 2. Edited by T. P. Crimes and J. C. Harper. Geological Journal, Special Issue 9.

Stanley, D. C. A., and R. K. Pickerill. 1993. Shallow marine Paleodictyon from the Upper Ordovician Georgian Bay Formation of southern Ontario. Atlantic Geology 29: 115-119.

Tevesz, M. J. S., and P. L. McCall. 1982. Geological significance of aquatic non-marine trace fossils. Pages 257285 in Animal-Sediment Relations. Edited by P. L. McCall and M. J. S. Tevesz. Plenum Publishing Company, New York.

Received 7 February 2002

Accepted 20 April 2004 